\title{
Observations of spawning in the Leather Bass, Dermatolepis dermatolepis (Teleostei: Epinephelidae), at Cocos Island, Costa Rica
}

\author{
Brad E. Erisman • Talina H. Konotchick • \\ Shmulik Blum
}

Received: 5 August 2008 / Accepted: 2 February 2009/Published online: 21 February 2009

(C) The Author(s) 2009. This article is published with open access at Springerlink.com

\begin{abstract}
Courtship and spawning behavior is described for the Leather Bass, Dermatolepis dermatolepis, from observations made from a manned submersible at Cocos Island, Costa Rica on 19 days between November 2006 and February 2007. Spawning occurred in the evening (16:00-18:30 h) in subgroups of 10-32 individuals that formed within aggregations of 50-70 individuals. The mating sequence was characterized by subgroup formation and crowding behavior followed by a brief vertical spawning rush, gamete release, and the rapid separation of participants. The aggregation was present on all dives, and spawning was not restricted to specific lunar phases.
\end{abstract}

Keywords Dermatolepis · Leather Bass ·

Spawning aggregation · Groupers .

Spawning behavior $\cdot$ Eastern Pacific

B. E. Erisman $(\bowtie) \cdot$ T. H. Konotchick

Scripps Institution of Oceanography,

University of California San Diego,

La Jolla, CA 92093, USA

e-mail: berisman@ucsd.edu

S. Blum

Undersea Hunter Group,

San Jose, Costa Rica

\section{Introduction}

Reef fishes exhibit a remarkable diversity of mating behaviors (Thresher 1984), but our understanding of this diversity is relatively poor in comparison with terrestrial animals (Owens 2006). Moreover, most information on the spawning behavior of reef fishes stems from observations and experimental manipulations of small species, and much less is known about the behaviors of larger, predatory species (Domeier and Colin 1997; Levin and Grimes 2002). This is unfortunate, since most large reef fishes are commercially exploited, and knowledge of their reproductive patterns is necessary to determine the effects of different fishing and management practices on population dynamics and to create effective conservation strategies (Levin and Grimes 2002; Rowe and Hutchings 2003).

The Leather Bass, Dermatolepis dermatolepis (Teleostei: Epinephelidae) (Fig. 1) is a medium-sized (to $1 \mathrm{~m}$ total length) grouper that inhabits rocky and coral reef habitats and feeds on small fishes and benthic crustaceans (Montgomery 1975). It is one of only three species in the genus Dermatolepis, and the only one found in the Pacific Ocean (Heemstra and Randall 1993). Although recorded from southern California to Ecuador, abundant populations of Leather Bass have been reported only on offshore islands such as the Revillagigedo Archipelago, the 


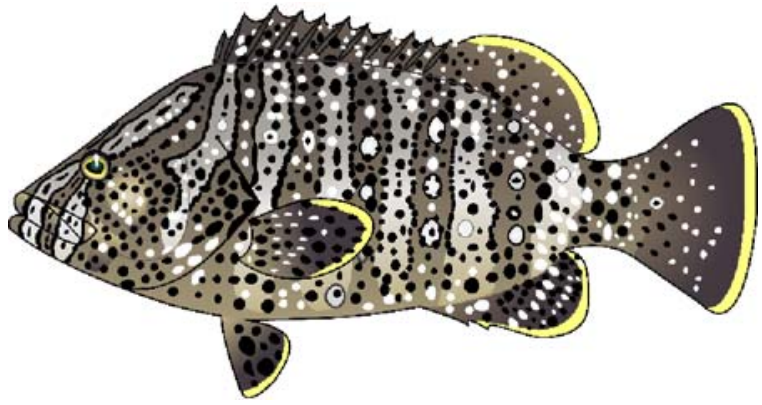

Fig. 1 The Leather bass, Dermatolepis dermatolepis. Drawing by LG Allen

Galapagos Islands, and Cocos Island (Allen and Robertson 1994; Grove and Lavenberg 1997; Garrison 2000). The reproductive patterns of Leather Bass are poorly understood; however, adults are reported to form spawning aggregations of fifty or more individuals (Aburto-Oropeza and Hull 2008). Also, spawning was recorded in July 1995 in the film "Secrets of the Ocean Realm: Creatures of Darkness" (Howard Hall productions, CMMVII Questar, Inc.) at Isla Manuelita, a small island located a few hundred meters off the northern coast of Cocos Island, Costa Rica. Here we provide the first detailed descriptions of courtship and spawning behavior in the Leather Bass from observations made from a mannedsubmersible at a seamount near Cocos Island.

\section{Methods}

Observations were conducted from DeepSee, a threeperson, one-atmosphere submersible with an acrylic viewing sphere. Spawning was first observed from 16:10 to $16: 30$ on 23 November 2006 at a seamount known as Everest, located ca. $1 \mathrm{~km}$ northeast of Isla Manuelita at Cocos Island, Costa Rica $\left(05^{\circ} 33^{\prime} \mathrm{N} ; 87^{\circ}\right.$ $\left.03^{\prime} \mathrm{W}\right)$. The base of the seamount lies $100 \mathrm{~m}$ below the surface, and it rises up to a peak at $50 \mathrm{~m}$ depth. The site is characterized by rocky substrate covered with coralline algae and small corals, and it houses a rich diversity of fish and invertebrate fauna.

We made subsequent observations at Everest from 27 November 2006 to 24 February 2007. A total of 27 submarine dives were made on 19 different days (Table 1). Dive durations ranged from 30 to $150 \mathrm{~min}$. Unfortunately, observations of Leather Bass were brief (c. 5-10 $\mathrm{min}$ ) and were made during routine ascents from surveys of deeper reefs. Therefore quantitative estimates of spawning were not measured; only the presence or absence of aggregating, courtship, and spawning behaviors were recorded. Visual estimates of the total lengths (TL) of individuals in the aggregations were also recorded during some observations. Specifically, size estimates were based on the length of fish relative to the known length of a steel support bar $(2.5 \mathrm{~m})$, located directly in front of the viewing window of the submersible.

Table 1 Timing and lunar phase of observations on the reproductive behavior of Leather Bass, Dermatolepis dermatolepis at Cocos Island, Costa Rica from November 2006 to February 2007. dafm $=$ days after full moon; $\mathrm{dbfm}=$ days before full moon. $\mathrm{A}=$ aggregating behavior, $\mathrm{C}=$ courtship behavior, $\mathrm{S}=$ spawning

\begin{tabular}{|c|c|c|c|}
\hline Date & Moon phase & Dive interval & Behavior \\
\hline \multirow[t]{3}{*}{ 23-Nov-06 } & \multirow[t]{3}{*}{$12 \mathrm{dbfm}$} & 0900-1030 & A \\
\hline & & $1130-1230$ & A \\
\hline & & $1530-1715$ & $\mathrm{~A}, \mathrm{C}, \mathrm{S}$ \\
\hline 27-Nov-06 & $8 \mathrm{dbfm}$ & $1230-1400$ & $\mathrm{~A}, \mathrm{C}$ \\
\hline 6-Dec-06 & $1 \mathrm{dafm}$ & $1500-1630$ & $\mathrm{~A}, \mathrm{C}, \mathrm{S}$ \\
\hline 8-Dec-06 & 3 dafm & $0845-1015$ & A \\
\hline 10-Dec-06 & $5 \mathrm{dafm}$ & 0900-0930 & A \\
\hline 11-Dec-07 & 6 dafm & 0900-1030 & A \\
\hline 15-Jan-07 & $12 \mathrm{dafm}$ & $1645-1800$ & $\mathrm{~A}, \mathrm{C}, \mathrm{S}$ \\
\hline \multirow[t]{3}{*}{ 16-Jan-07 } & \multirow[t]{3}{*}{$13 \mathrm{dafm}$} & 0900-1000 & A \\
\hline & & $1130-1230$ & A \\
\hline & & $1530-1700$ & $\mathrm{~A}, \mathrm{C}, \mathrm{S}$ \\
\hline 17-Jan-07 & 14 dafm & 0830-1100 & A \\
\hline 23-Jan-07 & $10 \mathrm{dbfm}$ & $1530-1730$ & $\mathrm{~A}, \mathrm{C}, \mathrm{S}$ \\
\hline \multirow[t]{2}{*}{ 31-Jan-07 } & \multirow[t]{2}{*}{$1 \mathrm{dbfm}$} & $1100-1300$ & $\mathrm{~A}, \mathrm{C}$ \\
\hline & & $1600-1715$ & $\mathrm{~A}, \mathrm{C}, \mathrm{S}$ \\
\hline 4-Feb-07 & $2 \mathrm{dafm}$ & $1630-1830$ & $\mathrm{~A}, \mathrm{C}, \mathrm{S}$ \\
\hline 5-Feb-07 & $3 \mathrm{dafm}$ & $1530-1745$ & $\mathrm{~A}, \mathrm{C}, \mathrm{S}$ \\
\hline \multirow[t]{3}{*}{ 7-Feb-07 } & \multirow[t]{3}{*}{5 dafm } & 0845-1015 & A \\
\hline & & $1200-1330$ & $\mathrm{~A}, \mathrm{C}$ \\
\hline & & $1615-1745$ & $\mathrm{~A}, \mathrm{C}, \mathrm{S}$ \\
\hline $11-F e b-07$ & $9 \mathrm{dafm}$ & 0830-1000 & A \\
\hline 12-Feb-07 & $10 \mathrm{dafm}$ & 0845-1015 & $\mathrm{A}$ \\
\hline 21-Feb-07 & $10 \mathrm{dbfm}$ & $1430-1600$ & $\mathrm{~A}, \mathrm{C}, \mathrm{S}$ \\
\hline 23-Feb-07 & $8 \mathrm{dbfm}$ & 0945-1115 & A \\
\hline \multirow[t]{2}{*}{ 24-Feb-07 } & \multirow[t]{2}{*}{$7 \mathrm{dbfm}$} & $1015-1115$ & A \\
\hline & & $1415-1530$ & $\mathrm{~A}, \mathrm{C}$ \\
\hline
\end{tabular}


Videos of behaviors were recorded with a digital camera from inside the submersible during observations made on 23 November 2006. Still frames captured from videos were used to estimate the size of the aggregation as well as the number of participants for two spawning rushes. Descriptions of courtship and spawning behaviors (i.e., lateral display, crowding, spawning rush) followed those by Domeier and Colin (1997) and Erisman et al. (2007) for other groupers.

\section{Results}

At 16:10 h on 23 November 2006, an aggregation of c. 70 adult Leather Bass was observed hovering just above the top of the seamount at depths of 48 to $50 \mathrm{~m}$ (Fig. 2). Most individuals were oriented into the prevailing current. A few individuals made sporadic movements around the aggregation and engaged in brief interactions (bumping, lateral displays) with conspecifics. The fish ranged in estimated size from 50 to $80 \mathrm{~cm}$ total length (TL) and exhibited similar color patterns. Their bodies were light grey and covered with numerous, small white blotches. Faint grey bars were present on some individuals and were most prominent along the dorsal portion of the body. The fins were dark grey to black with narrow, bright yellow margins. Color change was observed in one individual during an intraspecific interaction. Upon approach of a nearby fish, the individual erected its dorsal fin, and the faint grey bars along its body darkened and became more conspicuous.

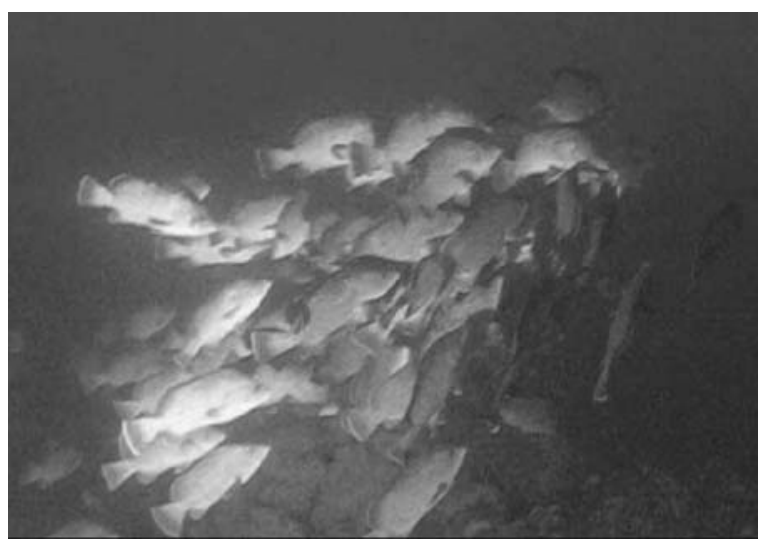

Fig. 2 Spawning aggregation of Leather Bass, Dermatolepis dermatolepis, at Cocos Island, Costa Rica
At 16:24 h, intraspecific activity increased and the entire aggregation rose slowly into open water, 3-5 m above the seamount or $45-47 \mathrm{~m}$ in depth. Three minutes later at $16: 27 \mathrm{~h}$, a pair of individuals positioned side-by-side and touching along their flanks performed a rapid, vertical spawning rush out from the top of the aggregation for $3 \mathrm{~m}$. These two fish were followed closely by a subgroup of 20-25 fish that separated from the larger aggregation immediately as the pair initiated their rush. During the spawning rush, members of the subgroup swam in close proximity to one another, often making physical contact with surrounding individuals (crowding behavior). At the apex of the ascent, which occurred at a depth of ca. $42 \mathrm{~m}$, the two lead fish separated and swam down towards the main aggregation. The pursuing subgroup followed the same swimming pattern as the lead fish, separating at the apex point and swimming back down to the main aggregation. This 4 s event was considered a 'false spawn', because gamete release by males (i.e., a cloud of sperm) was not observed.

Spawning was observed at $16: 28 \mathrm{~h}$ within a subgroup of 32 individuals that formed in the open water $3 \mathrm{~m}$ above the seamount. The subgroup first consisted of a lead individual, likely a gravid female, with an enlarged abdomen that was 'crowded' by seven surrounding individuals. The subgroup swam rapidly in a horizontal direction for $2 \mathrm{~m}$, turned upwards, and performed a vertical spawning rush of $3 \mathrm{~m}$ (Fig. 3) to a depth of ca. $40 \mathrm{~m}$. As this event developed, ca. 25 other fish separated from the main aggregation and joined the subgroup in the spawning rush. At the apex point, the lead individuals released gametes (evident from a visible cloud of sperm), separated rapidly and swam back down towards the top of the seamount. The remaining members of the subgroup followed the pathway of the lead individuals, swimming rapidly through the apex point before separating from the subgroup and swimming down towards the reef. A cloud of gametes formed at the apex of the spawning rush and grew in size as more and more individuals from the subgroup passed through it. The spawning event was $6 \mathrm{~s}$ in duration.

We documented spawning on 10 of 27 dives conducted from 23 November 2006 to 24 February 2007 at Everest (Table 1). During the study period, aggregations of 50 or more adult Leather Bass were present throughout the day, and courtship behavior 


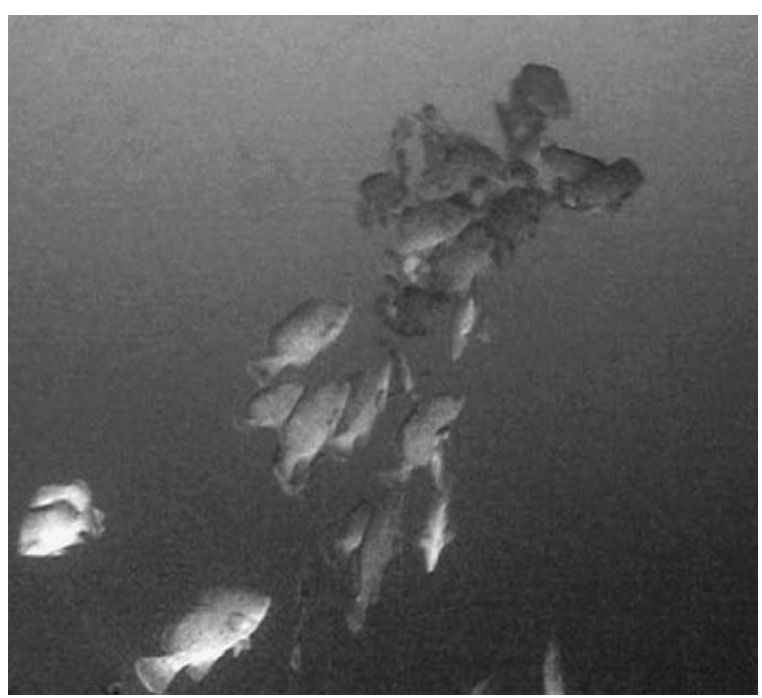

Fig. 3 Spawning rush of Leather Bass, Dermatolepis dermatolepis, at Cocos Island, Costa Rica

was observed on all dives that occurred at 13:00 $\mathrm{h}$ or later. Spawning events were observed on all dives that were performed from 16:00 to $18: 30 \mathrm{~h}$, and they occurred at depths of $40-50 \mathrm{~m}$. The progression of behaviors during courtship was similar to those described above (Fig. 4), and spawning events included 10-32 fish. Individuals in the aggregations ranged in total length from 40 to $90 \mathrm{~cm}$.

\section{Discussion}

Spawning in the Leather Bass at Everest seamount occurred in tightly packed subgroups of 10-32 fish that formed during the evening within larger aggregations of 50-70 fish. The mating sequence was characterized by subgroup formation and crowding behavior followed by a brief vertical spawning rush, gamete release, and the rapid separation of participants. Aggregations were present throughout the study period, and spawning activity showed no clear relationship with the lunar cycle. Overall, the behaviors observed in Leather Bass at Everest were similar to those captured in the film "Secrets of the Ocean Realm: Creatures of Darkness" (Howard Hall productions, (MMVII Questar, Inc.) at nearby Manuelita Island in 1995 and those described for other groupers that form aggregations and spawn in groups (Colin 1992; Erisman et al. 2007).
Our results contain both similarities and differences to previous reports on the reproductive patterns of the Leather Bass. The habitat, size, and seasonality of the spawning aggregation at Everest were consistent with descriptions by Aburto-Oropeza and Hull (2008) at the Revillagigedo Islands, Mexico. In that study, spawning aggregations of 30-54 fish were observed on 22 February 2007 over a shallow seamount. Conversely, spawning was filmed on 22 July at Manuelita Island in 1995, which suggests that the spawning season for Leather Bass at Cocos varies annually or occurs throughout the year. Previous reports on spawning periodicity also differ with results from this study, as aggregations were observed only on the day before the new moon at the Revillagigedo Islands (Aburto-Oropeza and Hull 2008) and 4 days before the full moon at Manuelita Island. Since estimates of spawning frequency (i.e., the number of spawns per unit time) at Everest were not measured, it is uncertain whether spawning activity peaked during certain lunar phases and thus followed a rhythm. However, our observations demonstrate that aggregating and spawning persisted for long periods and were not restricted to certain lunar phases. Spawning during specific lunar phases is common among groupers that form spawning aggregations (Thresher 1984; Sadovy 1996; Levin and Grimes 2002), but non-lunar spawning has been reported for a few species (Hereu et al. 2006; Erisman et al. 2007). Based on the results of this and previous studies on Leather Bass, it is clear that additional research is needed to understand both spatial and temporal variations in the spawning patterns of this species. This will require detailed information on temperature, photoperiod, and other environmental cues known to stimulate and regulate spawning in groupers (Shapiro 1987; Colin 1992; Sadovy et al. 1994; Sadovy 1996; Hereu et al. 2006).

Spawning aggregations appear to be an important part of the reproductive activity of Leather Bass. Due to their predictability in both time and space, spawning aggregations of reef fishes are particularly vulnerable to overfishing and thus are primary targets for conservation (Colin et al., 2003; Claydon 2004; Sadovy and Domeier 2005; Sadovy de Mitcheson et al. 2008). Leather Bass are not significant components of commercial fisheries in most mainland regions of the eastern Pacific, but they are targeted by artisanal and recreational fisheries at certain 
Fig. 4 Ethogram of a spawning event of Leather Bass, Dermatolepis dermatolepis, at Cocos Island, Costa Rica. a The aggregation forms above the top of the seamount; $\mathbf{b}$ a subgroup of several individuals separates from the main aggregation and swims into open water; c members of the subgroup perform a vertical spawning rush, release their gametes, and separate to return to the main aggregation

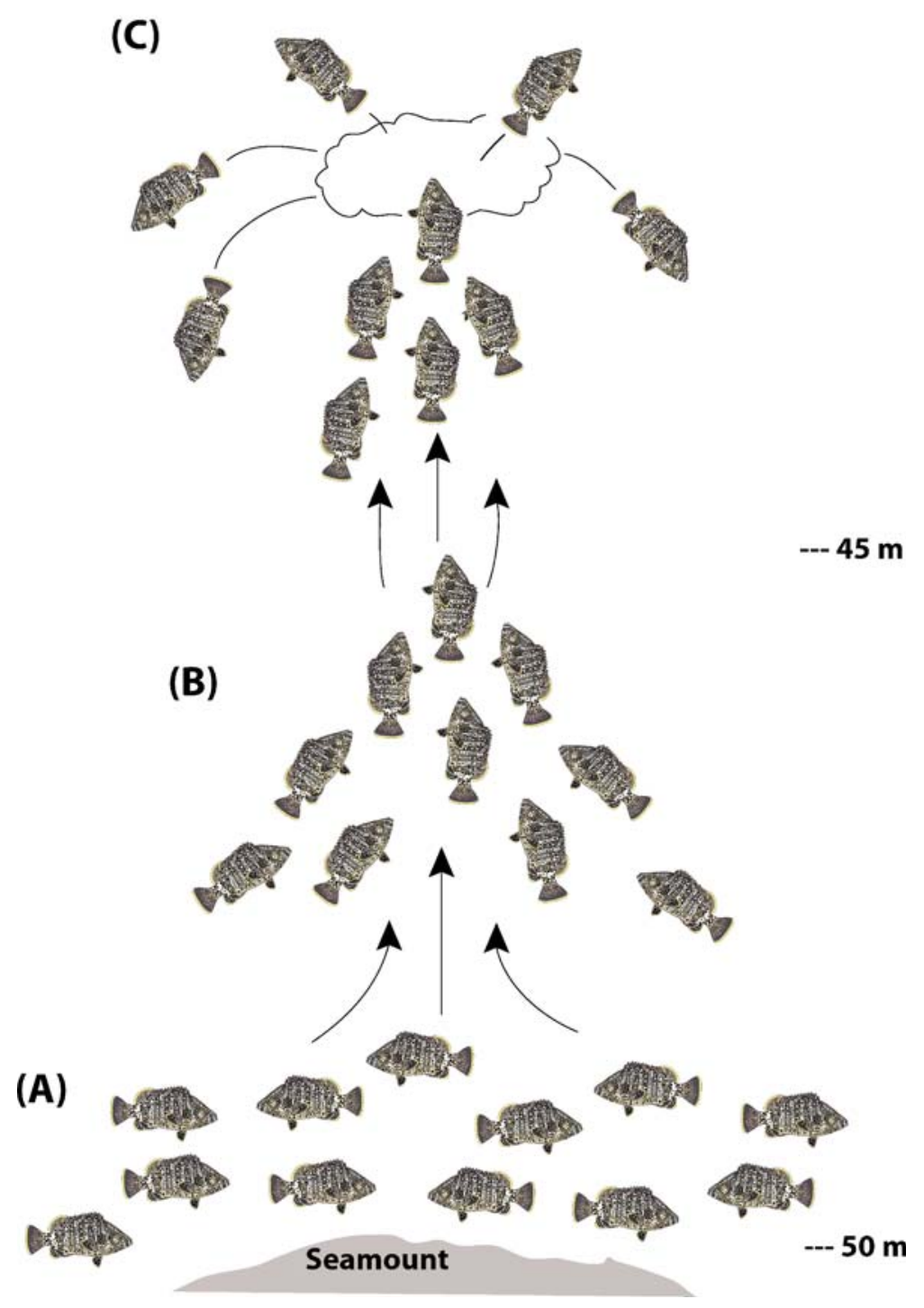

offshore islands (Heemstra and Randall 1993). A study on artisanal fisheries at the Galápagos Islands found that Leather Bass populations were absent in areas that were heavily fished, which indicates that the species is sensitive to exploitation (Ruttenberg 2001). Management policies for the Leather Bass do not exist; however, their restriction to offshore islands of the eastern Pacific, tendency to form spawning aggregations, and vulnerability to fishing all point to a need for protection. Developments of appropriate conservation strategies for this species will require precise information on spawning seasonality, including the timing and locations of aggregations.

Acknowledgements Many thanks to S. Drogin, the crew of DeepSee, Argos and Undersea Hunter, and the SIO Research Diving Program for providing the opportunity to visit and conduct research at Cocos Island. S. Drogin provided financial support for this project. Several programs at Scripps Institution of Oceanography provided logistical and other support: the Research Diving Program, Center for Marine Biodiversity and Conservation, and the E.B. Scripps Foundation. L. Allen provided the illustrations, and P. Hastings, R. Rosenblatt, M. 
Craig, G. Galland, and R. Warner provided helpful comments for this manuscript.

Open Access This article is distributed under the terms of the Creative Commons Attribution Noncommercial License which permits any noncommercial use, distribution, and reproduction in any medium, provided the original author(s) and source are credited.

\section{References}

Aburto-Oropeza O, Hull PM (2008) A probable spawning aggregation of the leather bass, Dermatolepis dermatolepis, in the Revillagigedo Archipelago, Mexico. J Fish Biol 73:288-295 doi:10.1111/j.1095-8649.2008.01909.x

Allen GR, Robertson DR (1994) Fishes of the tropical eastern Pacific. University of Hawaii Press, Honolulu

Claydon J (2004) Spawning aggregations of coral reef fishes: characteristics, hypotheses, threats, and management. Oceanogr Mar Biol 42:265-302

Colin PL (1992) Reproduction in the Nassau grouper, Epinephelus striatus (Pisces:Serranidae) and its relationship to environmental conditions. Environ Biol Fishes 34:357377 doi:10.1007/BF00004740

Colin PL, Sadovy YJ, Domeier ML (2003) Manual for the study and conservation of reef fish aggregations. Soc Cons Reef Fish Agg Spec Pub 1:1-98

Domeier ML, Colin PL (1997) Tropical reef fish spawning aggregations: defined and reviewed. Bull Mar Sci 60:698-726

Erisman BE, Buckhorn MB, Hastings PA (2007) Spawning patterns in the leopard grouper, Mycteroperca rosacea, in comparison with other aggregating groupers. Mar Biol (Berl) 151:1849-1861 doi:10.1007/s00227-007-0623-2

Garrison G (2000) Peces de la Isla del Coco: Isla del Coco Fishes. Instituto Nacional de Biodiversidad (inbio), Santo Domingo, Costa Rica

Grove JS, Lavenberg RJ (1997) The fishes of the Galápagos Islands. Stanford University Press, Stanford
Heemstra PC, Randall JE (1993) Groupers of the World. FAO species synopsis no. 125, vol. 16. FAO, Rome

Hereu B, Diaz D, Pasqual J, Zabala M, Sala E (2006) Temporal patterns of spawning of the dusky grouper Epinephelus marginatus in relation to environmental factors. Mar Ecol Prog Ser 325:187-194 doi:10.3354/meps325187

Levin PF, Grimes CB (2002) Reef fish ecology and grouper conservation and management. In: Sale PF (ed) Coral reef fishes: dynamics and diversity in a complex ecosystem. Academic Press, Amsterdam, pp 377-390

Montgomery WL (1975) Interspecific associations of seabasses (Serranidae) in the Gulf of California. Copeia 1975:785787 doi: $10.2307 / 1443342$

Owens IPF (2006) Where is behavioural ecology going? Trends Ecol Evol 21:356-361 doi:10.1016/j.tree.2006.03.014

Rowe R, Hutchings JA (2003) Mating systems and the conservation of commercially exploited marine fish. Trends Ecol Evol 18:567-572 doi:10.1016/j.tree. 2003.09.004

Ruttenberg BI (2001) Effects of artisanal fishing on marine communities in the Galápagos Islands. Conserv Biol 15:1691-1699 doi:10.1046/j.1523-1739.2001.99556.x

Sadovy Y (1996) Reproduction in reef fishery species. In: Polunin NVC, Roberts CM (eds) Reef Fisheries. Chapman and Hall, London, pp 15-60

Sadovy de Mitcheson Y, Cornish A, Domeier M, Colin PL, Russell M, Lindeman KC (2008) A global baseline for spawning aggregations of reef fishes. Conserv Biol 22:1233-1244 doi:10.1111/j.1523-1739.2008.01020.x

Sadovy Y, Domeier ML (2005) Are aggregation-fisheries sustainable? Reef fish fisheries as a case study. Coral Reefs 24:254-262 doi:10.1007/s00338-005-0474-6

Sadovy Y, Rosario A, Román A (1994) Reproduction in an aggregating grouper, the red hind, Epinephelus guttatus. Environ Biol Fishes 41:269-286

Shapiro DY (1987) In: Polovina JJ, Ralston S (eds) Tropical snappers and groupers, biology and fisheries management. Westview Press, London, pp 295-327

Thresher RE (1984) Reproduction in reef fishes. T F H Publications, Neptune City, New Jersey 